\title{
11. \\ KULA STOJANA JANKOVIĆA: \\ ISTRAŽIVAČKI PRISTUPI I NEKE \\ DETERMINANTE U FORMIRANJU \\ PROJEKTNIH KONCEPATA
}

\section{Ivan Basić}

UDK: 904:72(497.5 Islam Grčki)

Sažetak: Autor raspravlja o svekolikom nasljeđu Kule Stojana Jankovića u Islamu Grčkom i njegovom smještanju u institucionalne okvire otvorene zainteresiranim istraživačima raznih profila. Dotiče sljedeća pitanja: relativnu vrijednost mobilizacije baštinskih potencijala, strateški plan mobilizacije potencijala lokaliteta, "otključavanje" hrvatskih baštinskih potencijala prema Europi i svijetu, suštinsku revitalizaciju, dugoročnu komercijalnu iskoristivost uređenoga lokaliteta, mobilizaciju lokalnih potencijala i ostvarivanje maksimalnih učinaka na dobrobit mikroregije.

Ključne riječi: Islam Grčki, Kula Stojana Jankovića, povijest, projekti, revitalizacija, sveučilišni centar

ula Stojana Jankovića u Islamu Grčkom, fenomen čijeg su povijesnog trajanja u različitim aspektima stekli vrlo divergentna čitanja, pa i aproprijacije, otvorila je velik broj ـpitanja vlastitih civilizacijskih i kulturnih stečevina u ponekad veoma složenim kontekstima. Budući da je time stekla pravo na posebno propitivanje, odgovore na neka od tih pitanja ponudio sam 2010. godine u knjizi Od domus episcopi do Kule Jankovića. Prostorni razvoj Kule Stojana Jankovića u Islamu Grčkom.

Geofizičke karakteristike Islama Latinskog i Grčkog s užom okolinom, pružaju brojne stabilne preduvjete i prednosti kontinuiranoj prisutnosti ljudskih naseobina, dok je geografska važnost područja iskazana i njegovom uklopljenošću u važnu komunikaciju od Nina, antičke Enone, do Knina. Usprkos tome što u Islamu nikada nisu provedena sustavna arheološka istraživanja, a za većinu nalaza pohranjenih u kolekciji Kule Stojana Jankovića ne postoje precizniji podaci o provenijenciji, nema sumnje da nalazi čine sastavni dio mozaika s lokalitetima u neposrednoj blizini. Sâmo područje Islama nalazilo se u antici po svemu sudeći u sklopu agera municipija Nedinum. U ranom srednjem vijeku inkorporirano je u županiju Luka. Širi areal današnjega Islama u srednjovjekovlju su zauzimala naselja Grgurice, Učitelja Vas, Tršćane, Kačina Gorica, Rejane, Paprčane, Kašić, Rocane, napokon 
Čerinci. Via Magna cesta vocata tendens per Lucam srednjovjekovna je komunikacija koja je tekla pravcem Nin - Islam - Kašić - Smilčić - Biljane Gornje - Benkovac - Ostrovica - Knin. Osam kilometara duga dionica prolazila je kroz srednjovjekovni Novigradski distrikt. Istraživanje života današnjega sela Islam (Grčkoga i Latinskoga) u srednjovjekovnom razdoblju otežano je nepoznavanjem srednjovjekovnog toponima toga naselja koji je u ranomu novom vijeku zamijenjen novim nazivom "bedem islama" (Sedd-i islâm). O tom problemu mnogo se raspravljalo, a tek je 1985. godine N. Jakšić, analizirajući izvornu građu, došao do zaključka kako se Islam u mletačkim aktima, još u 16. stoljeću, spominje kao utvrđeno selo Učitelja Vas, što je predturski toponim ovog naselja.

Jedno od najvažnijih uporišta za proučavanje toponimije Islama jest povelja od 16. kolovoza 1266. godine, kojom Roland, "ban čitave Slavonije" (banus totius Sclavonie), daruje ninskoj crkvi biskupa Samsona II. posjed Četiglavac (Chetiglavaz), precizno definirajući njegove međe. Opisane međe odnose se na toponime područja današnjih naselja Islam Grčki i Islam Latinski. Usporedbom toponimâ registriranih u privilegijima posedarskim knezovima iz 1219. i 1249. godine sa spomenutim podacima iz 1266. godine, zatim s mletačko-osmanlijskim razgraničenjem kakvo je ustanovljeno od 1576. godine nadalje, napokon s općom slikom stanja u katastru iz 1826. godine, bilo je moguće precizno rekonstruirati jugozapadnu među veleposjeda posedarskih knezova prema povijesnom teritoriju Islama (odnosno sjeveroistočnu granicu posjeda ninskog biskupa). Utvrđeno je kako se taj limes u dugom razdoblju od 13. do 19. stoljeća doslovno nije mijenjao. Neobično je važna činjenica da se Kula Jankovića nalazi upravo na potezu južne međe posjeda biskupa Samsona, na neprijepornoj dionici koja prelazi preko crkve sv. Jurja (na položaju Crkvice, nepunih pola kilometra zapadno od Kule). Domus episcopi Sansonis, biskupova ladanjska rezidencija, tako je vrlo uvjerljivo poistovjećena s današnjom Kulom Jankovića.

Učitelja Vas spada u red naselja koja su depopulizirana nakon učestalih osmanlijskih zalijetanja u hrvatski teritorij tijekom 15. i 16. stoljeća. Već prije Ciparskog rata ono se nalazilo na pograničnom području, kao "ničija zemlja" između mletačkoga Acquisto vecchio i novoformiranog "vilajet Hrvati”. Ferhad-paša Sokolović zauzeo je Učitelja Vas 1570. godine. Doskora je naselje brisano u korist osmanlijske pogranične utvrde usmjerene prema mletačkom posjedu i prikladno nazvane "bedem islama", Sedd-i islam. Mada Evliya Çelebi u svom putopisu Seyahatname (oko 1631. - 1670.) pripisuje osnutak ove utvrde Gazi Husrev-begu (1538.), zadarski povjesničari Š. Ljubavac i C. F. Bianchi njegovo utemeljenje smještaju mnogo realnije u 1577. godinu. Turski kaštel razrušen je iz preventivnih razloga početkom Kandijskoga rata 1647. godine, po naređenju providura Leonarda Foscola. Linija mletačko-osmanlijskog razgraničenja na ovoj je mikroregiji tekla u neposrednoj blizini nekadašnjeg sela Učitelja Vas, preko Grgurica pa sve do Paljuva. Mirom iz 1669. godine sultanu je vraćen sav osvojeni teritorij osim malenih dijelova srednje Dalmacije. Upravo su u Islamu 1671. godine Mahmud-paša i G. B. Nani bilateralno odredili granice Dalmacije nakon Kandijskog rata - tzv. linea Nani.

Mletački uspjesi, ma kako efemerni, ne bi bili zamislivi bez morlačkog faktora i nove mletačke oportune politike prema njemu. Izbjegle Morlake Serenissima je u Dalmaciji opskrbljivala potrebnim oružjem koje su oni potom "uskočivši” u stari kraj, koristili protiv Turaka. Vlasnici Kule, obitelj Mitrović-Janković, na povijesnu pozornicu izlaze sredinom 17. stoljeća te postaju nasljednim upraviteljima Gornjih Kotara. Stojan Janković (MitrovićJanković) godine 1663. postaje jednim od mjesnih poglavara Posedarja. Za svoje ratne zasluge i lojalnost Republici sv. Marka u leno je 1670. godine primio posjed srednje veličine 
u Islamu. Već iduće godine imenovan je zapovjednikom Ostrovice, a 1681. godine postaje čelnikom Morlaka. Poginuo je u pohodu na Glamoč, Livno i Duvno 1687. godine i ne vidjevši svoga lena u Islamu. Davnašnja imanja ninskog biskupa ušla su, čini se, neizmijenjena, u sklop osmanlijskoga Islama nakon 1576 . godine. Do 1670 . godine nalazila su se u posjedu Jusuf-age Tunića, a kako su površinom približno odgovarala starom posjedu ninskih biskupa prilično je uvjerljiva pretpostavka o njihovoj prenamjeni u jedan spahiluk za vrijeme osmanlijske ere. Svakako im se barem neko vrijeme prije 1670. godine međe nisu mijenjale. No "Stojanovi dvori" kakve danas poznajemo s ovim protagonistom dalmatinske povijesti zapravo nemaju izravne veze (mada u oralnoj, epskoj tradiciji o Stojanu islamska Kula zauzima istaknuto mjesto). Iz rasutih i rijetkih izvora da se koliko-toliko rekonstruirati skelet zbivanja u 17. stoljeću: 1647. godine osmanlijski kaštel je razoren; 1671. godine, za vrijeme sastanka Nanija i Mahmud-paše Islam je još "ruina", nakon čega se vraća pod osmanlijsku nadležnost, da bi ga ovi već 1684 . godine napustili; Stojan Janković pogiba 1687. godine, a situacija oko Islama sankcionirana je tek krajem rata, dvanaest godina kasnije. Tek će se nakon Morejskog rata 1699. godine Jankovići smjestiti na svojim zemljama, što će kulminirati izgradnjom obiteljskih dvora na novostečenim posjedima u stoljećima koja su dolazila.

Više naznaka ukazuje kako jezgru postojećeg sklopa Dvora treba tražiti u zgradama koje je Todorin Dede Janković kupio 1719. godine. Ono što danas nazivamo Kulom Jankovića jedinstven je sklop gospodarskih, fortifikacijskih i rezidencijalnih objekata protegnutih na površini od $4500 \mathrm{~m}^{2}$. Nalazi se na brežuljku zapadno od stare "Velike ceste" koja ga tangencijalno dotiče, južno od Islama Grčkog. Čitav kompleks obrubljen je visokim kamenim zidovima, koji ga ocrtavaju kao nepravilan pravokutnik $(80 \times 60 \mathrm{~m})$. Unutar njega čitavu sjeverozapadnu trećinu zauzima gospodarsko-rezidencijalno-fortifikacijska jezgra. Ona je oblikovana kao trokrilna građevina s aneksom izvan jugozapadnog ugla. Krila tog cijelog sjeverozapadnog segmenta unutar sebe zatvaraju unutrašnje dvorište koje je kasnijim podizanjem gospodarskih zgrada uz cijeli sjeveroistočni rub posjeda gotovo posve zatvoreno, $s$ tek malenim prolazom između većeg i manjeg dvorišta. Najstariji dio raspoznaje se u "Staroj kući” u sredini južnoga krila jezgre. Aneks ("Kula") oblikovan je kao višeetažni toranj, nadvisujući čitav sklop. Citavim južnim tj. jugoistočnim dijelom prospekta nižu se od jugozapada k jugoistoku: "Tamnica" s "Kužinom", "Kula", "Stara kuća" (s glavnim ulazom u stari dio kompleksa) i "Kotarina". Pretpostavlja se da je najstariji dio same stare jezgre dvokatna zgrada čija su oba prostora natkrivena bačvastim svodom. Njen suterenski dio, "Tamnica", djelomično ukopan u tlo, koristio se kao podrumska prostorija, a gornji kat, "Stara kužina", kao kuhinja. Na jugozapadnoj strani te prvobitne jezgre - koja čitava pod nazivom "Kula" objedinjuje "Tamnicu", "Staru kužinu" i "Kulu" - nalazi se najreprezentativnija prostorija, "Sala", smještena u jugozapadnom uglu, između "Stare kuće" i Kule sa "Starom kužinom" i "Tamnicom”. Djelomično čini nadgradnju "Ćelije”. Sa "Starom kućom” povezuje ju predprostor nazvan "Ispred Sale". "Straža" i "Ispred sale" tako čine komunikacijsko čvorište cijele strukture Dvora. Spomenutoj građevini pod nazivom "Sala" pridodan je u zapadnom produžetku tijekom 18. stoljeća objekt čije je prizemlje konstruirano od četiri široka luka, jednim dijelom otvorena prema "Maloj avliji". Ta prostorija, "Ćelija”, služila je kao podrumski prostor. "Ćelija" se na zapadu nastavljala u dvoetažno južno-jugozapadno krilo, čijom je izgradnjom u 18. stoljeću započeto formiranje "Male avlije", a dvorac zakoračio u transformaciju od jednokrilne u dvokrilnu strukturu. "Mala avlija" oblikovala se neravnomjerno, u pojedinim potezima objekata koji su markirali njene rubove, sve do 
posljednje trećine 19. stoljeća. Iz tog vremena datira jednoetažna zgrada (“Cimentana kuća", "Magazin") koja je, zajedno sa susjednim ekonomskim zgradama, definirala sjeverni odnosno sjeveroistočni potez "Male avlije". Nasuprotno južno, odnosno jugoistočno krilo kompletirano je izgradnjom "Kotarine" kao pandana "Stare kuće", također u 19. stoljeću. $\mathrm{Na}$ taj je način pri kraju tog stoljeća kompleks Dvora činio tlocrt U-oblika, grupiranjem prostora na dvije razine oko "Male avlije" (s iznimkom "Stare kuće" kao jedine dvokatnice).

Neprekidnim proširivanjem građevine, adicijama koje su ostvarili različiti vlasnici od početka 18. stoljeća nadalje, ona je postala trokrilnom rezidencijom oko dubokog pravokutnog dvorišta. Dominantni građevinski volumen, međutim, nije u dnu dvorišta, već lateralno, u masama u uglu, pomaknut u odnosu na glavnu os. Time se tlocrtni princip podredio zatečenom stanju, staroj jezgri koja je formalno i sadržajno zadržana kao prostorno središte i dominanta. Naknadnim podizanjem poprečne zgrade s pojatama u produžetku sve do kraja "Velike avlije", gotovo je u potpunosti dokinuta trokrilnost dvora, pretvorivši ga u kompaktni četverokrilni blok s unutarnjim dvorištem. Prelaskom u posjed obitelji Desnica, Vladimir Desnica i njegovi nasljednici obvezali su se dovršiti radove na kompleksu, što je i oporučno zatražio posljednji conte Janković, Ilija Dede (†1874.). Novi vlasnici su u kasnijim godinama također izvodili radove na dvorima. Možda najobuhvatnija kampanja provedena je za Uroša Desnice, tridesetih godina 20. stoljeća, u okviru jedne "historizacije" većih razmjera. Sâmi dvori znatno su oštećeni već za savezničkih zračnih napada tijekom II. svjetskog rata. Duga obnova završena je tek šezdesetih godina, a već nešto prije je dio "Stare kuće" zalaganjem pisca Vladana Desnice postao pristupačan javnosti kao minijaturni etnografski muzej. Nasljednici V. Desnice nastavili su provoditi dugoročne planove prenamjene Kule u muzejski prostor. Od 1988. do 1991. godine izvršena je konsolidacija i konzervacija niza zgrada. U Domovinskom ratu ukupan je prostor Ravnih kotara doživio teških destrukcija, posebno sakralni objekti, pa je u tim nesretnim ratnim okolnostima stradao i kompleks Jankovića Dvora zajedno s crkvom sv. Đurđa (sv. Jurja). Uz "Staru kuću" i crkvu, najviše su pretrpjeli zapadni i južni dio kompleksa. Trenutno je baština Dvora Jankovića rasuta između muzeja u Benkovcu, Biogradu, Beogradu, Zadru i Zagrebu. Od 2003. do 2005. godine "Stara kuća" je sanirana, dok su "Sala" i "Ispred sale" 2006. godine predložene za osnovnu sanaciju Ministarstvu kulture Republike Hrvatske te im je popravljen krov. Zid "Novog stana" popravljen je i učvršćen 2007., da bi iduće godine i on dobio novi krov.

Istraživački se nikada ne bi smjelo previdjeti da se radi o objektu izrazite arhitektonske, ali i kulturne slojevitosti, čije je kontinuitete i povijesne rezove moguće pomno iščitati i rekonstruirati jedino kritičkim preispitivanjem konteksta, poduprtim poznavanjem svih dostupnih vrela. Građevine ovoga tipa su - ne samo u arhitektonskom pogledu - kvalitativno nova pojava, strukturalno drugačija u odnosu na istovrsne utvrde srednjovjekovnog razdoblja. Tim je začudnije što kao korpus kule dalmatinskoga zaleđa nisu dostojno istražene, iako konstituiraju respektabilnu baštinu i bitne su za cjelinu regionalnog, dalmatinskog i hrvatskog kulturnog nasljeđa uopće. U središtu je interesa navedene knjige, iz svih ovih razloga, bio ne samo građevinski sklop Kule, već i dublja prošlost naselja i mikroregije na kojima je taj sklop konfiguriran, poglavito kroz srednji vijek i razdoblje osmansko-mletačkih sukoba tijekom 16. i 17. stoljeća. Nimalo jednostavan zadatak sintetiziranja dosadašnjih saznanja i novih spoznaja o Kuli Jankovića uključivao je savladavanje nemalog broja izvora i literature različitih vremenskih i žanrovskih provenijencija te proisteklih iz različitih disciplina (arheologija, povijest, povijest umjetnosti, etnologija, onomastika i dr.), zatim jezikâ i grafija, historiografskih tradicija itd. Doda li se tome da je bilo potrebno iščitavanje temelj- 
nih antičkih i srednjovjekovnih vrela epigrafičkog i narativnog karaktera, kao i konzultiranje neobjavljenih arhivskih izvora kartografske i upravno-administrativne provenijencije, postaje jasnim da se radilo o višestranom procesu, često kolaborativna tipa, provođenom u interakciji s pregrštom različitih istraživača u Zagrebu, Zadru, kao i na samom terenu. Upravo ovo potonje, izravna autopsija spomenika i njegova okružja, omogućilo je najneposredniju istraživačku komunikaciju s ambijentom. Podrazumijeva se da je rad na tekstu iziskivao i kritička čitanja, osobito u novije vrijeme umnožene, znanstvene, stručne pa i popularne literature, često proturječna predznaka. Druga su istraživanja koja su nastajala u vezi s ovima zasebno vrednovana te su našla put do znanstvene javnosti. Jedna su s drugima bila komplementarna te je u odgovarajućem izdanju Centra za komparativnohistorijske i interkulturne studije obrađen onaj segment baštine mikroregije kojeg je knjiga Od domus episcopi do Kule Jankovića tek usputno doticala: etnološko i onomastičko blago.

Spomenuta baština, kako u narativnim i ideografskim vrelima, tako i u arheološkim tragovima te sačuvanim ambijentima, otvara dalekosežne mogućnosti proučavanja tek iščekujući svoga istraživača. Naravno, preduvjet svakog ozbiljnije zasnovanog pothvata toga tipa jest dostupnost svekolikog nasljeđa Kule Jankovića akademskoj zajednici i kulturnoj javnosti, tj. njegovo smještanje u institucionalne okvire otvorene zainteresiranim istraživačima raznih profila.

Pritom, kao i za svaku drugu spomeničku jedinicu ili kompleks - neovisno o vremenu njegova nastanka i apsolutnoj vrijednosti - za Kulu Stojana Jankovića vrijedi jednak princip. Suštinsko je pitanje relativna vrijednost mobilizacije baštinskih potencijala. Ona se ocjenjuje u okviru relacije: vrijednost spomenika - održivo okruženje spomenika. U tom je smislu ilustrativan primjer Dubrovnika, čija gradska jezgra i spomenici imaju veliku vrijednost kao kulturna dobra, ali je pritom još znatnije što se, istovremeno, nalaze u okruženju koje već posjeduje uspostavljen sustav financiranja održavanja baštine. Uz to valja naglasiti $\mathrm{da}$ - čak i ako spomenuti sustav ne bi postojao - dubrovačka gradska jezgra neprijeporno raspolaže financijskim osnovama za njegovo uspostavljanje (svakovrsnim ubiranjem prihoda na licu mjesta). Radi se, dakle, u slučaju Dubrovnika, o problemu uspostavljanja djelotvornoga sustava upravljanja spomenicima, a ne o procjenjivanju vrijednosti kulturne baštine, koja je neosporna. Isto tako, navedeni primjer ukazuje na opasnosti posljedicâ lošeg upravljačkog sustava na stanje baštine, koja uslijed narušenog funkcioniranja sustava, iz raznih razloga, često ostaje zanemarena. U druge primjere, u izvjesnoj mjeri usporedive sa situacijom i budućom namjenom Kule Jankovića, ubrajaju se, primjerice, Han Jusufa Maškovića u Vrani (rijedak primjer održane arhitektonske cjeline osmanlijskoga razdoblja, također predviđen za sveučilišni centar), Bribirska Glavica (antička Varvaria, srednjovjekovni Bribir), zatim sjeverozapadna kula Dioklecijanove palače u Splitu (u kojoj već više desetljeća djeluje Mediteranski centar za graditeljsko nasljeđe kao interfakultetsko istraživačko središte Sveučilišta u Splitu i Arhitektonskog fakulteta Sveučilišta u Zagrebu), palača Moise u Cresu (istraživački centar za humanističke i društvene znanosti Sveučilišta u Rijeci), a u manjoj mjeri i renesansni ljetnikovac Sorkočević na Lapadu kod Dubrovnika, sjedište dubrovačkog Zavoda za povijesne znanosti Hrvatske akademije znanosti i umjetnosti (za detaljnije informacije v. prilog Alana Brauna).

Među signifikantna, fundamentalna istraživanja koja bi pri istraživačkom raslojavanju arheološke i povijesne stratigrafije Kule Jankovića i pripadajućeg joj prostora tek trebalo provesti svakako se ubrajaju, primjerice, sondažna i/ili sustavna arheološka iskopavanja crkve sv. Jurja i groblja koje okružuje građevinu, zatim znanstvena revalorizacija osmanske 
komponente baštine Kule Jankovića (kako u arhitektonsko-tipološkoj obradi sâmog objekta, tako i u neveliku broju očuvane pokretne baštine), napokon studiozna analiza odrazâ transformacije arhitektonskog sklopa od fortifikacijskog u zemljoposjednički u 18. i 19. stoljeću, s promjenama u načinu života, orijentiranu prema urbanim kriterijima, da istaknemo samo neke zadaće. Provedba sanacije i obnove tijekom Domovinskog rata teško destruiranog kompleksa, a koju već nekoliko godina sufinancira Ministarstvo kulture Republike Hrvatske, pruža osobito povoljne preduvjete raščlanjivanju arhitektonskih slojeva građevine, koji su se recentnim zahvatom očitovali na njenim raskrivenim zidnim plaštevima. Stara je jezgra Kule očigledno tijekom duge povijesti pretrpjela višekratne pregradnje, razvidne u upotrijebljenim materijalima, tehnici i strukturi gradnje. No, recentni trendovi financiranja - kako od strane Ministarstva kulture, tako i drugih institucija - upućuju na dalekosežne promjene u dosadašnjim praksama novčanog podupiranja ovakvih zahvata. Ukoliko, naime, isti ne budu koncipirani u okviru šire zasnovanih programa poticanja lokalnoga socioekonomskog razvoja uporabom rezultata znanstvenih istraživanja, neće se ozbiljnije financirati, dok će novčano podupiranje zaštite i sanacije zatečenih struktura biti svedeno na ograničenu mjeru, u cilju jednostavnog fizičkog održavanja spomenika, odnosno lokaliteta. Arheološka verifikacija očigled no veoma složene kulturne slike kompleksa Kule Jankovića predstavlja jedan od zadataka koji tek predstoje u rasvjetljavanju mjesnoga i regionalnog povijesnog gibanja, a prirodnu stožernu ustanovu, kako u programskom tako i u koordinacijskom smislu, nalaze u Međunarodnom sveučilišnom centru koji će biti lociran u sâmoj Kuli. Međusveučilišna arheološka suradnja s integriranom komponentom suradnje inozemnih arheologa specijaliziranih za navedeno polje istraživanja i istraživački zainteresiranima za nj nesumnjivo bi urodila i stabilnijom financijskom konstrukcijom.

Dakle, ako se govori o vrednovanju potencijala određene spomeničke baštine, kao primarna zadaća nameće se izrada strateškog plana mobilizacije potencijala toga lokaliteta. U idealnim projekcijama, spomenuti bi plan trebao obuhvaćati što je moguće duže vremensko razdoblje. Suvremeni europski standard u tom smislu iznosi 4 godine, ali u mnogim zemljama (primjerice, Japanu) proteže se čak na 25 godina. Početak takvog oblikovanja izrade strateškoga plana odnosi se, u biti, na "osobnu iskaznicu" spomenika, odnosno lokaliteta te čini suštinski preduvjet za inozemno financiranje bilo kojeg tipa (Europska komisija ili drugi investitori). U dokumentu o kojem je riječ moraju biti previđene sve osnovne smjernice za daljnji razvoj lokaliteta - financijske, upravljačke itd. U trenutku kada zainteresirane strane raspolažu navedenim dokumentom, načinjenim temeljem kvalitetnih postojećih standarda, spomenik ili lokalitet postaje iznimno prihvatljiv za inozemne donatore/investitore. Valja naglasiti da tekući standardi kao prihvatljivu normu podrazumijevaju osnovnu upravljačku strukturu koja ne funkcionira na hijerarhijskom principu vrhovnog dužnosnika na mjestu voditelja, već na egalitarnom principu suodlučivanja o svim bitnim pitanjima.

Treba imati na umu da se nalazimo u vrlo specifičnom kontekstu kada je Hrvatska pred vratima Europske unije ${ }^{1}$ i, u pogledu iskoristivosti fondova i mogućnosti plasiranja naše baštine, radi se o ključnom trenutku. Interesi naše zemlje trenutačno se podudaraju s interesima postojećih europskih financijskih platformi u domeni znanosti i kulture, u smislu promocije baštine hrvatskoga povijesnog prostora. Političkom odlukom postajemo dio europske zajednice država, a samim tim činom i hrvatska nacionalna, regionalna i lokalna

1 Napomena: tekst je pisan u studenom 2012. godine. 
baština postaje dijelom normativne, udžbeničke baštine u državama-članicama. Stoga je za očekivati da će se interes za našu baštinu uvelike povećati, a s njime i financiranje prezentacijskih projekata. To pak znači da se nalazimo, unatoč recesiji, na pragu novoga zadatka integracije hrvatske baštine s onom europskom. Tom će zadatku dorasli biti - i u novim okolnostima opstati - prije svega oni projekti koji su na vrijeme anticipirali nov, europski kontekst, kao i oni koji će se na najbolji mogući način moći prilagoditi zadanom projektnom okviru. Odlučan postupak u tim novim projektnim izazovima jest, dakle, sposobnost otključavanja hrvatskih baštinskih potencijala prema Europi i svijetu (unlocking of potentials), što se u mnogim natječajima tijekom posljednjeg desetljeća pokazalo presudnim mehanizmom pri prepoznatljivosti u ovome sektoru od strane Europske komisije.

Međutim, srž mobilizacije baštinskih potencijala ne leži samo u restauraciji lokaliteta/ spomenika, nego u njegovoj suštinskoj revitalizaciji. Odrješit odgovor na pitanje što jest stvarna revitalizacija u suvremenim uvjetima ne može se još uvijek dati, ali prema dosadašnjim okolnostima i perspektivama, radi se o dugoročnoj komercijalnoj iskoristivosti uređenoga lokaliteta, koja se očituje kroz dugoročnu sposobnost lokaliteta da generira vlastita financijska sredstva kroz neinvazivne aktivnosti koje se odvijaju u sklopu njega. Stoga potreba za formuliranjem kvalitetna plana u tom cilju postaje akutnom i prvorazrednom. Pokazalo se, također, da je Europska komisija, kao i drugi relevantni donatori/investitori, prije svega zainteresirana za financiranje projekata koji uključuju mobilizaciju lokalnih potencijala i ostvarivanje maksimalnih učinaka na dobrobit mikroregije. U svemu dakle maločas navedeno znači da u projektnoj praksi željeni cilj za bilo koji budući projekt vezan uz Kulu Stojana Jankovića mora računati s pronalaženjem realnog (financijskog i inog) značaja za širu okolicu i poduzetnike toga kraja. Sve ovo, dakako, podrazumijeva jačanje suradnje $s$ mjesnim i nacionalnim znanstvenim i kulturnim ustanovama, nadležnim službama zaštite spomenika na svim razinama te s jedinicama lokalne samouprave.

Činjenica što trenutno promocija kulture kroz fondove Europske komisije - poglavitog investitora u tekućem razdoblju - nije "site-specific", ima blagotvorne posljedice, makar u ovom konkretnom primjeru nosi i pojedine otegotne učinke. Potonji se prije svega odnose na činjenicu što Kula Jankovića kao fenomen, jedinstven kompleks, predstavlja primjer spomenika kakav je u mikroregiji manje-više prostorno, sadržajno i programski izoliran od sličnih sadržaja. Ponuda projektnih programskih okosnica, naime, podrazumijeva šira partnerstva i šire konceptualne osnove vezane za teme koje su vezane za ulogu spomeničke baštine u razvoju društva ili pojedinih zajednica. No, u navedenom smislu Kula Jankovića ima i priličan potencijal - radi se o ratom pogođenom području (što se u okviru europskog financiranja u više navrata pokazalo presudno pozitivnim), kao i o višestoljetnoj platformi multikulturalnih perturbacija u vrlo osjetljivu kraju, što sve zajedno Kulu čini iznimno prihvatljivim odredištem postojećih projektnih tendencija Europske unije.

Svede li se sve što je dosada izloženo u koncizne okvire, održiv razvoj u pogledu Kule Jankovića znači sljedeće:

1. Daljnji razvoj upravljačkog sustava, koji će generirati sredstva za daljnje funkcioniranje Kule kao kulturno-znanstvenog središta. Razvoj bi trebao obuhvaćati uspostavu sustava koji će omogućiti redovito funkcioniranje lokaliteta, uključujući promociju, organizaciju događanja, definiranje programa rada Kule, plan ulaganja u daljnja istraživanja. U ovoj su etapi ključne mjere zaštite Ministarstva kulture Republike Hrvatske: pod mjere zaštite valja podvesti ovu vrstu iskorištavanja lokaliteta. 
2. Diversifikacija aktivnosti koje se odvijaju u Kuli i oko nje, bilo da se radi o arheološkim istraživanjima, izložbama, kongresima, seminarima, etnofestivalima, turističkim priredbama i svim ostalim sličnim aktivnostima. Naime, jedino takva diversifikacija u svim smjerovima može mjesto poput ovoga učiniti šire vidljivim i poznatim javnosti. Suštinski, diversifikacija mora nužno biti bazirana na konzistentnom strateškom planu razvoja Međunarodnoga sveučilišnog centra vezanoga uz dio sadržajâ Kule, odnosno na SWOT analizi (Strengths, Weaknesses, Opportunities and Threats). Drugim riječima, trebalo bi identificirati sve prednosti, snažnije strane (sklopa i onoga što se u njemu odvija) i minimizirati, u najvećoj mogućoj mjeri, realne nedostatke (npr. zabačeni položaj kompleksa, nerazvijena i siromašna okolina, neprepoznatljivost). Bez tog koraka, daljnje upravljanje sadržajnom stranom Kule Jankovića nije dugoročno ostvarivo. Za diversifikaciju djelatnosti u Kuli i oko nje dosadašnjim su potezima (godišnji kulturno-znanstveni skup Desničini susreti, međunarodni volonterski kampovi, Ljetna škola) već položeni dobri temelji. Od 2003. godine Ministarstvo kulture RH financira postupnu obnovu kompleksa Kule Jankovića. Iste godine posvećen joj je podprojekt "Mostovi-Revitalizacija Kule Stojana Jankovića i područja sela Islam Grčki, Islam Latinski i Kašića” u sklopu projekta Triplex Confinium: Hrvatska višegraničja u euromediteranskom kontekstu. Od 2009. do 2010. godine Europska je unija (EIDHR) financijski podržavala rad na Kuli u sklopu projekta Old Castle - New Bridges (“Stara kula - novi mostovi”), nastavljenog 2010. - 2011. projektom Old Castle - More Bridges. Ujedno je bila pod paskom projekta Valoriziranje i zaštita kulturne baštine iz venecijanskog razdoblja u zalecu Zadra (Hrvatska) pri odsjecima za povijest Sveučilišta u Padovi i Filozofskog fakulteta u Zagrebu (voditelji prof. dr. Egidio Ivetic i prof. dr. Drago Roksandić), a u okviru Interreg III projektne inicijative Europske unije. U zasnivanju Međunarodnog sveučilišnog centra "Kula Jankovića", prostorije za koji je ugovorom između Sveučilišta u Zagrebu i vlasnikâ kompleksa osigurano $700 \mathrm{~m}^{2}$ iskoristivog prostora i to na tridesetogodišnje razdoblje (2011. - 2041.), leži i budući potencijal da se čitav kompleks transformira u regionalni znanstveno-kulturni centar (obuhvaćajući svu interdisciplinarnost srodnih poljâ: od povijesnih znanosti, do etnologije, prirodnih znanosti poput biologije i sl.).

U spektru različitih vrsta valorizacijâ lokaliteta - iz kulturno-povijesne, turističke, kulturno-turističke, konzervatorske, etnološke, poslovne itd. perspektive - valjalo bi inzistirati na povijesne i ambijentalne vrijednosti Kule Jankovića. Povijesna vrijednost i simbolički potencijal tog sklopa detaljno su objašnjeni u nedavnim publikacijama pa nije ovdje mjesto opetovanju tih odlika. $U$ ambijentalnom pak smislu Kula posjeduje potencijal da postane jedna od ključnih spona između mainstream hrvatske kulture i "osebujne" kulture dalmatinskoga zaleđa. Pomalja se, dakle, mogućnost spašavanja i čuvanja određenih etnoloških fenomena, uz ekonomsko iskorištavanje ponekih među njima, prihodi kojega bi se nadalje ulagali postupnim širenjem istog procesa na slične sadržaje u mikroregiji i regiji. Tako zamišljena programska okosnica potpuno se uklapa u propozicije namjenskih europskih fondova. U tom dugoročnom programu prepoznaje se iznimna važnost Centra koji je zamašnjak čitava projekta valorizacije Kule i njene pune, stvarne revitalizacije u doglednoj budućnosti. Centar, u kombinaciji s kvalitetno razrađenim njegovim planskim aktivnostima (vidi gore) igra, naime, veoma važnu ulogu u bilo kojem pokušaju sveobuhvatnije valorizacije Kule. Śtoviše, u ovom je trenutku upravo Centar ono što kompleks Jankovićâ pozicionira na višu vrijednosno-značenjsku razinu od one koju bi ovaj sklop zauzimao sam 
po sebi, sa svojim kulturno-povijesnim nasljeđem. Stoga je daljnje razvijanje Centra posve neophodno jer će upravo njegovim razvojem postupno rasti i vrijednost lokaliteta.

3. Podizanje prepoznatljivosti Kule kao kulturnoga (ili znanstvenoga ili kulturno-turističkoga) središta. U ovom je pogledu Kula Jankovića još uvijek nedovoljno razvijena. $S$ jedne strane, naime, aktivnosti vezane uz taj prostorni sklop dobro su razvijene ili na solidnu putu da to postanu, dok s druge strane regionalna i međunarodna prepoznatljivost Kule Jankovića još uvijek nije prevelika. Valja napomenuti da je rečeno jedan od uvjeta za dugoročno financiranje od strane europskih fondova. Hvalevrijedni početni koraci pri formiranju prepoznatljivosti Kule u tom smislu svakako su publikacije vezane uz nju (v. popis literature); nedovoljno je naglaska položeno na njenu međunarodnu dostupnost, kako zbog jezične barijere, tako zbog ograničene difuzije (uglavnom samo u nacionalnim ili regionalnim okvirima). Prevođenje postojeće i produciranje nove relevantne literature o Kuli na svjetskim jezicima svakako je poželjan korak u pravom smjeru. Uz to se prirodno vezuje uspostavljanje snažnije međunarodne razmjene tekuće literature, kao $\mathrm{i}$ internacionalizacija kulturno-znanstvenih aktivnosti vezanih uz Kulu (nadilaženjem sudionikâ nacionalne i/ili regionalne pripadnosti). Nadalje, u budućnosti bi bilo nužno kvalitetno istupiti $s$ informativnim i promotivnim materijalima o Kuli i njezinim sadržajima kroz druge medije i na različitim jezicima (npr. snimanje dokumentarne emisije ili emisija o Kuli, što ne bi iziskivalo dodatna financijska sredstva jer se umjesto televizijskog dokumentarca može načiniti i jednostavna serija filmova, internetski objavljena na YouTubeu, koji gledanošću ionako nadilazi televizijski program; nadalje, potrebna je izrada kvalitetne internetske stranice, ustanoviti distribuciju brošura na CD-ima itd.). Jasno prepoznatljive razvojne strategije Centra - diversifikacija programa, umnažanje produkcije, edukacija i prijenos znanja te orijentacija prema partnerstvu i suradnji - čine temelj budućega razvoja.

Ukoliko bismo željeli sažeti "legitimaciju” sklopa Kule Jankovića u nekoliko točaka s povijesnoumjetničkog motrišta, navedeno bismo mogli, u najvažnijim sastavnicama, učiniti na sljedeći način:

- kulturno-umjetnički najvredniju sastavnicu predstavlja središnji stambeno-fortifikacijski sklop, što se odnosi na cjelokupan kompleks (dvori s pripadajućim neizgrađenim površinama unutar ogradnog zida, kako onima privedenima hortikulturi tako i ostalima) u čitavoj njegovoj arhitektonskoj slojevitosti razlučivoj od 18. do 20. stoljeća; radi se o kompleksu nesumnjivih arhitektonskih kvaliteta, kako u prostornoj artikulaciji tako i u dispoziciji, kakvi su rijetko sačuvani u domaćoj baštini, a gotovo sasvim manjkaju primjeri kontinuirano sačuvani u prvotnoj namjeni i vlasništvu obitelji utemeljitelja;

- crkva sv. Jurja nedaleko Kule predstavlja značajan sakralni objekt, s mogućom romaničkom jezgrom, dok je okolno groblje prema nizu indikacija potencijalno veoma zahvalan arheološki lokalitet, sa slojevima koji sežu u prapovijesno razdoblje;

- pokretni umjetnički inventar (provenijencijom iz Kule i crkve sv. Đurđa) različitog tipa, materijala i dimenzija, sačinjava baštinu koja je neodvojiv vizualni, likovni i ikonografski činitelj cjelokupnoga kompleksa Kule Jankovića (u ovaj korpus valja uključiti i pisanu baštinu, tj. arhivalije i liturgijske knjige koji se čuvaju na licu mjesta ili u drugim ustanovama u zemlji i izvan nje, a koje bi valjalo na izvjestan način objediniti u muzeološki jedinstveno zamišljenoj koncepciji). 


\section{cos}

\section{Literatura}

Aa. Vv., Aid Delivery Methods. Vol. 1: Project Cycle Management Guidelines, European Commission, EuropeAid Cooperation Office, Brussels, 2004.

Baвić, Darko i Marijeta Rajкоvić Iveta. 2009. "Prilog za razvoj ekomuzeja u Ravnim kotarima”. Studia ethnologica Croatica, 21:307-329., vol. 32 (5):555-591

Basić, Ivan. 2010. Od domus episcopi do Kule Jankovića. Prostorni razvoj Kule Stojana Jankovića u Islamu Grčkom. Zagreb: Centar za komparativnohistorijske i interkulturne studije Filozofskog fakulteta; FF-press..

Brigović, Ivan i Ante Nazor. 2007. “Kontinentalna Dalmacija u Domovinskome ratu”. U Dalmatinska zagora - nepoznata zemlja. Galerija Klovićevi dvori, 4. rujna - 21. listopada 2007., ur. J. Belamarić, M. Grčić. Zagreb: Galerija Klovićevi dvori, 287-291.

Brtan, Josip. 2002. Župa Islam Latinski. Sinj-Split: Matica hrvatska, Geografsko društvo.

Č́nnelić, Milana i Marijeta Rajković Iveta, ur. 2010. Zapisi iz gornjih Ravnih kotara. Etnološki, povijesni i muzeološki prilozi o Islamu Latinskom, Islamu Grčkom, Kašiću i Podgradini. Zagreb: Centar za komparativnohistorijske i interkulturne studije Filozofskog fakulteta; FF-press.

Čolović, Branko. 2007. “Sakralna baština Srba u kontinentalnoj Dalmaciji”. Dalmatinska zagora - nepoznata zemlja. Galerija Klovićevi dvori, 4. rujna - 21. listopada 2007., ur. J. Belamarić, M. Grčić. Zagreb: Galerija Klovićevi dvori, 333-341.

Desnica, Boško. 1991. Stojan Janković i uskočka Dalmacija: izabrani radovi, prir. S. Volarević. Beograd: Srpska književna zadruga.

Desnica, Vladan. 1975. Eseji, kritike, pogledi. Zagreb: Prosvjeta. (Sabrana djela Vladana Desnice, knj. IV).

Gluščević, Smiljan i Ivo Fadić. 1985. "Antički predmeti u Kuli Stojana Jankovića”. Zadarska revija, XXXIV/4-5:321-333.

Gušıć, Branimir. 1971. "Starohrvatsko naseljenje Ravnih kotara”. Radovi Instituta JAZU u Zadru, XVIII:137-192.

Ivetic, Egidio i Drago Roksandić. ed. 2007. Tolerance and Intolerance on the Triplex Confinium. Approaching the "Other" on the Borderlands Eastern Adriatic and beyond 1500-1800. Padova: Università degli Studi di Padova, Dipartimento di Storia.

Jakšić, Nikola. 2000. Hrvatski srednjovjekovni krajobrazi. Split: Muzej hrvatskih arheoloških spomenika.

JAKšić, Nikola. 2008. "Il ruolo delle antiche chiese rurali nella formazione del ducato croato medievale”. Hortus Artium Medievalium, 14:103-112.

JurIć, Radomir. 1985. “O mogućoj muzeološkoj obradi Islama Grčkog i Dvora Stojana Jankovića”. Zadarska revija, XXXIVI4-5:439-446.

Jurković, Miljenko. ur. 1992. Od Nina do Knina: iz hrvatske spomeničke baštine od 9. do 11. stoljeća. Od Ninske biskupije do katedrale hrvatskog biskupa u Biskupiji kod Knina. Zagreb: Muzejskogalerijski centar-Muzej Mimara, Gliptoteka HAZU.

Kos, Lucijan. 1987. "Bukovica i Ravni kotari (historijsko-geografsko, ekonomsko-prometno i političko-upravno značenje)”. Benkovački kraj kroz vjekove. Zbornik 1, ur. J. Medini. Benkovac-Zadar: Narodni list, Općinska konferencija SSRNH, Filozofski fakultet, 65-82.

Maraković, Nikolina i Tin Turković. 2009. "Ciklus edukacijskih radionica "Menadžment kulturne baštine - modeli istraživanja, zaštite i gospodarskog vrednovanja” (Skradin-Bribir 2008/2009)". Studia Varvarina, vol. 1, ur./ed. B. Kuntić Makvić, Zagreb: Međunarodni istra- 
živački centar za kasnu antiku i srednji vijek/International Research Center for Late Antiquity and Middle Ages, 153-162.

Maraković, Nikolina, Tin Turković i Maja Zeman. 2009. [2011]. "Edukacijske radionice "Menadžment kulturne baštine - modeli istraživanja, zaštite i gospodarskog vrednovanja" projekta "IRCLAMA" Međunarodnog istraživačkog centra za kasnu antiku i srednji vijek Sveučilišta u Zagrebu (Skradin - Bribir, 2008./2009.). Hrvatski arheološki godišnjak, 6:728-731.

Maynew, Tea. 2008. Dalmatia between Ottoman and Venetian Rule. Contado di Zara 1645-1718, Padova: Università degli Studi di Padova, Dipartimento di Storia; Viella.

Medini, Julijan. 1985. "Iz antike Ravnih kotara”. Zadarska revija, XXXIV/4-5:309-320.

Milutinović, Kosta. 1968. “Od Stojana Jankovića do Vladana Desnice”. Zadarska revija, XVII/1:9-37.

Nemec, Krešimir. 1988. Vladan Desnica. Zagreb: Zavod za znanost o književnosti Filozofskog fakulteta.

Roksandić, Drago. 2000. "Stojan Janković nella guerra di Morea ovvero degli uscocchi, degli schiavi e dei sudditi". Atti del Centro di ricerche storiche - Rovigno, XXX:315-390.

RoKsAndić, Drago. 2003. "Inicijativa obnove i oživljavanja Kule Stojana Jankovića u selu Islam Grčki”, Prosvjeta, X (XXXV)/55 (665):29-31.

RoKsANDIĆ, Drago. 2007. “Dalmatinska zagora u ranome novom vijeku: pitanja za raspravu”. U Dalmatinska zagora - nepoznata zemlja. Galerija Klovićevi dvori, 4. rujna - 21. listopada 2007., ur. J. Belamarić, M. Grčić. Zagreb: Galerija Klovićevi dvori, 185-194.

Roksandić, Drago i Ivana Cvijović. ur. 2010. Zbornik radova “Desničini susreti 2005.-2008.”. Zagreb: Plejade.

SAvić, Milorad. 2003. Ilija Dede Janković: prilozi za biografiju. Zagreb: SKD "Prosvjeta".

SAvić, Milorad. 2006. Baština dvora Jankovića. Beograd: Istorijski muzej Srbije.

Sinobad, Marko. 2008. "Prilog poznavanju kule Janković Stojana”, Ljetopis SKD "Prosvjeta”, XIII:168-178.

Stanojević, Gligor. 1962. Dalmacija u doba Morejskog rata 1684-1699. Beograd: Vojno delo.

STANOJEVIĆ. Gligor. ur. 1970. Jugoslovenske zemlje u mletačko-turskim ratovima XVI-XVIII vijeka. Beograd: Istorijski institut.

Starac, Alka. 2000. Rimsko vladanje u Histriji i Liburniji. Društveno i pravno uređenje prema literarnoj, natpisnoj i arheološkoj gradi. II. Liburnija. Pula: Arheološki muzej Istre.

Suić, Mate. 1981. Zadar u starom vijeku. Zadar: Filozofski fakultet.

SuIć, Mate. 2003. Antički grad na istočnom Jadranu. Zagreb: Golden marketing, ${ }^{2} 2003$.

Turković, Tin i Nikolina Maraković. 2009. "Projekt IRCLAMA Međunarodnoga istraživačkog centra za kasnu antiku i srednji vijek Sveučilišta u Zagrebu”. Kvartal: kronika povijesti umjetnosti u Hrvatskoj, VI/1-2:94-97.

UGLešić, Ante. 2002. Ranokršćanska arhitektura na području današnje Zadarske nadbiskupije. Zadar: Filozofski fakultet u Zadru, Odsjek za arheologiju; Zadarska nadbiskupija.

VEŽIĆ, Pavuša. 1985. "Pretpostavke za suvremenu namjenu i zaštitu Kule Jankovića u Islamu Grčkom”. Zadarska revija, XXXIV/4-5:447-450.

VEŽIĆ, Pavuša. 2006. Zadar na pragu kršćanstva. Arhitektura ranoga kršćanstva u Zadru i na zadarskome području. Zadar: Arheološki muzej. 